\title{
The Effect of Polarization on Economic Growth, Social Capital, and Democracy: A Cross-Country Study
}

\author{
Maham Zahra Mehdi (Corresponding Author) \\ Karachi University Business School, University of Karachi, Pakistan \\ Tel: 92-347-200-7204Ｅ-mail: mahamzahra@gmail.com \\ Danish Ahmed Siddiqui \\ Karachi University Business School, University of Karachi, Pakistan \\ E-mail: daanish79@hotmail.com
}

Received: June 1, 2020 Accepted: June 27, $2020 \quad$ Published: June 29, 2020

doi:10.5296/ieb.v6i1.17116 URL: https://doi.org/10.5296/ieb.v6i1.17116

\begin{abstract}
In the last decade, one of the biggest global issues that have been debated upon is whether increased rates of migration, diversity, and political polarization stemming from these factors have any impact on the economic growth of countries. Accordingly, this paper explores the effect of polarization on democracy, social capital, education, and economic growth in a cross-country analysis involving developed countries, developing countries, and the least developed countries. A bilateral time series analysis was conducted by treating each country-set in isolation, as well as a group and focusing on the period 2009 to 2018 . According to our results, polarization appears to have a negative effect on the economic growth of developing countries. The same results were observed when we analyzed all the countries collectively. An inverse relationship was also established between polarization and social capital in developed countries. Meanwhile, polarization does not have any significant impact on democracy and education for any of the countries under study. It was also determined that when treated independently, democracy, social capital, education, and GDP per capita all appear to have a varying yet negative effect on polarization.
\end{abstract}

Keywords: Political polarization, Social capital, Economic growth, Developed countries, Developing countries, Least developed countries, Democracy, education 


\section{Introduction}

\subsection{Background to the Study}

In recent times, there has been a rise in political polarization. Some of the primary causes of this include the rise of identity-group politics, growing religious, racial, and ethnic diversity, geographical sorting, the rise of media ghettos, and the decline of journalistic responsibility. The rise of identity politics has led to the creation of group identities - the Left Wing and the Right Wing. There has also been a rise in religious diversity in Western democracies such as the United States of America. Today, religious beliefs play an important role in an individual's political affiliation. The increase in racial and ethnic diversity has also contributed to social and political conflicts. However, these changes in race composition and ethnicity may be beneficial in the long run. Geographical sorting has been described as a cause of polarization, as well, with individuals living in politically like-minded communities. The rise of media ghettos and lack of journalistic responsibility has contributed to polarization in western economies. Previously, the media was guided by censorship, fact-checking, and professionalism. Currently, however, access to digital media platforms allows any individual to post 'news'. There is little credibility left and verifying information is difficult.

Polarization can have positive, as well as negative effects on democracy, social capital, and economic growth. As per (Glassman, 2017), (Moreno, 2017), (Enyedi, 2006), (Enyedi, 2008), (LeBass, 2011), and (LeBas, 2018), reasonable levels of political polarization benefits democracy and strengthens political parties. This is due to greater political participation and the simplification of political choice when it comes to casting votes.

Some of the negative impacts of polarization on democracy include legislative gridlock, declining voter efficiency, and conflicts between civilians having different political ideologies.

In the case of social capital, polarization may affect government effectiveness and hurt legislative processes, leading to government inefficiency. Instead of developing centrist policies, governments may introduce measures that only benefit their supporters.

Polarization appears to have varying impacts on economic growth, as well. It can have an indirect, negative impact on economic growth by contributing to political instability and adversely affecting the economy. On the other hand, when polarization occurs due to higher rates of migration, it can boost economic performance in developing countries.

\subsection{Problem Statement}

Global progress toward sustainable development continues to be uneven, with an uneven growth trajectory being observed for developed, developing, and least developed countries (UNCTAD, 2019). It is important to understand how these growth trajectories are influenced by polarization, social capital, and democracy. Understanding these relationships can allow us to take appropriate measures to encourage or discourage political discourse that leads to partisanship and help accelerate sustainable development in these countries. On the other 
hand, failing to account for these relationships may reduce the effectiveness of initiatives designed to uplift the economic status of these countries.

At present, there are a variety of theories about how polarization influences economic growth. These impacts can vary as per the economic status of a country. We must isolate the impact of political polarization and understand how it varies across different economic regions of the world.

\subsection{Gap Analysis}

Currently, no economic model exists explaining the impact of political polarization on economic development. However, several studies have helped us understand the impact of political polarization on democracy, social capital, and economic development for a particular country or region. This does not provide a holistic picture of how political polarization can vary across country sets.

(Roe, 2008) has discussed the impact of political instability on financial development in a cross-country study. However, their analysis was limited to financial development and does not discuss other economic, social, and political indicators. Moreover, (Roe, 2008) measures political instability through a political stability index that relies on severe political downturns such as military coups and political assassinations. In recent times, political instability can be the product of polarizing ideologies that promote sentiments of partisanship within a community (race supremacy, ethnic tension, etc). In this study, we attempt to identify the role of such elements in contributing to political polarization and their impact on the economic development of developing, least developed, and developed countries.

(Bove \& Elia, 2017) also examine the relationship between migration, diversity, and economic growth. This study stipulates that migration and diversity have a positive impact on the economic growth of countries. It primarily relies on cultural diversity resulting due to migration as a determinant for economic growth. It accounts for fractionalization and polarization, however, the impact of polarization on economic development is treated as secondary. The primary focus is on isolating the effect of immigration on a country's GDP. We believe that one must also consider general levels of ethnic tensions and political conflicts to examine the impact of political polarization on economic growth.

(McCoy et al., 2018) studies the impact of polarization on democracy. This study examines the effect of polarization for 4 countries - Hungary, Venezuela, Turkey, and the USA. Key findings suggest that the upper, elite class played an essential role in the promotion of political polarization in these countries. This eventually led to the political mobilization of different groups in each respective. However, since this study focused on the effect of polarization on democracy for 4 isolated cases, it is difficult to determine whether the same relationship can be observed for other countries and how these impacts vary according to the economic status of the country. Additionally, none of the countries included in the study fall into the category of least developed countries. Further research is required to examine the effect of political polarization on democracy across the globe.

(Guiso, et al., 2000) examines the impact of social capital on financial capital and democracy 
in Italy. As per the study, strong social capital can influence financial decisions undertaken in the community. Since the study was limited to Italy, it is difficult to ascertain a pattern for how social capital may influence financial development and democracy in other countries. (Knack \& Keefer, 1997) studied the relationship between social capital and economic performance for 29 market economies by measuring trust and civic norms. As per the findings, strong levels of social capital were observed for countries with more equal and higher income levels. However, this study does not discuss the impact of other variables such as government effectiveness, rule of law, and regulatory quality on economic performance. Additionally, it does not explore the impact of social capital across different economies.

As per the above analysis, no such study was undertaken to account for the effects of polarization on least developed, developing, and developed countries while discussing diverse social, political, and economic indicators that could be affected by polarization. Hence, this is a novel attempt in this regard.

\subsection{Research Objectives}

The purpose of this research is to identify whether political polarization has a significant relationship with democracy, social capital, and economic growth. We will also attempt to address how this relationship varies across countries and provide a theoretical framework that supports our results.

Our dataset compares the effect of these variables on countries based on their economic status. Previous studies conducted on these variables published results for one particular country or region. We hope to provide a more holistic picture by including countries that differ in terms of their economic health.

\subsection{Significance of Research}

We will examine the impact of political polarization on democracy, social capital, and economic growth across different countries located in different geographical regions and with different economic and political challenges. Through this research, we can suggest a review of current national policies that contribute to polarization within a country and affect economic growth.

\subsection{Literature Review}

The existing literature on polarization is based on single-case and cross-country studies.

A 2014 study by (Papyrakis \& Mo, 2014) examined the effects of ethnic fragmentation and polarization on economic growth. It was discovered that ethnic fragmentation negatively influences activities linked to economic growth.

(Karnane\& Quinn, 2019) also examined the relationship between political instability, ethnic fractionalization, and economic growth. The research examined the direct impact of ethnic fragmentation, lack of political stability, and corruption on economic growth for 157 countries. It was discovered that ethnic fractionalization and corruption indirectly hurt economic development by accelerating political instability in a country that adversely 
impacts economic growth.

Education may also play a significant role in controlling polarization. As per (Houston, 2019), polarization and depolarization appear to be linked to the education policy of a country. It suggests that greater expenditure on education leads to depolarization.

(Montalvo \& Reynal-Querol, 2003) have examined the effect of religious polarization on economic performance. The study proposed that religious polarization and diversity have a greater impact on economic development than ethnic fragmentation. The results of the study supported this view.

(Brzezinski, 2013) also examined the study of income polarization on economic growth for 70 countries and focused on the 1960 to 2005 period. It was discovered that income polarization has hurts economic growth on a short term basis.

(Bove \& Elia, 2017) studied the relationship between migration, diversity, and economic growth. According to this study, when migrants arrive in a new country, they bring with them a new range of skills, capabilities, and opinions which promotes technological innovation and encourages economic development. However, the rise in migration influences social cohesion within a community. The study suggested migration and cultural diversity have a positive impact on a country's GDP with developing countries benefiting the most from these factors.

We have also reviewed available literature on the effects of social capital on economic growth and democracy in a country. (Guiso et al., 2000) examined the impact of social capital on democracy and financial development in Italy. As per results, areas with strong levels of social capital appear to have the following characteristics: 1 . The average household will use checks often. 2. They will make fewer investments in cash and favor investments in stock. 3 . They rely on institutional credit over informal credit. The study also suggested that the effect of social capital is heightened in areas where the law enforcement infrastructure is weak. Literacy levels also determine the influence of social capital on an economy.

A study by (Gylfason, 2019) examined the relationship between income equality and economic diversification, the rule of law, and transparency. As per the results obtained, inequality of income distribution hinders democracy in a country. It also interferes with economic growth.

(Marsh, 2000) examined the relationship between social capital and democracy and its significance regarding Russia's attempt to develop a democratic system of governance. The evidence suggested that strong social capital is associated with a strong democracy. It was concluded that social capital facilitates the development of a democratic system of governance in communist societies. The study also pointed out that high stocks of social capital were essential to achieve this. A region with insufficient social capital will suffer from government ineffectiveness and local authoritarianism.

(Knack \& Keefer, 1997) examined the relationship between social capital and economic performance by sampling data from 29 market economies. They used indicators for trust and civic norms to measure social capital and its effect on economic performance. It was 
discovered that strong social capital is more prevalent in countries with higher incomes and income equality. Additionally, nations with ethnically homogenous populations with higher literacy levels performed better than nations that did not exhibit these factors. The study concluded that higher levels of social capital have a positive impact on economic performance.

(McCoy et al., 2018) reviewed the impact of polarization on democracy. The researchers conducted research on Hungary, Venezuela, Turkey, and the United States of America to evaluate the relationship between democracy and polarization. It was found that the elite section of society played an essential role in the construction or intensification of divisive sentiments within the country which led to the subsequent mobilization of a marginalized segment of the population. In many cases, an economic crisis also contributed to political mobilization. In Hungary, Venezuela, and Turkey, new political groups formed that brought changes on a constitutional level to consolidate their political position. In the case of the United States, there was no modification in the constitution of the country.

(Tavits, 2006) proposed a link between social capital and the performance of the government and explored whether social capital improves democracy through policy activism and administrative efficiency. The results indicated that while social capital does appear to enhance policy activism, it does not have a significant effect on administrative efficiency.

(van Deth, 2007) also examined the relationship between social capital, political engagement, and democracy. It was proposed that if social capital improves political engagement, then this can strengthen and improve democracy. The researchers concluded that voluntary relationships formed due to social capital are positively related to political engagement.

(Acemoglu, Naidu, Restrepo, \& Robinson, 2014 established a positive relationship between democracy and GDP per capita. As per the results, democratizations can enhance GDP per capita by $20 \%$ in the long term through increased investment in education and health. (Narayan, Narayan, \& Smyth, 2011) examined how democracy and economic growth are related by gathering data from 30 countries in sub-Saharan Africa. As per the results, a rise in GDP improves democracy and increases real income in the long term. However, a negative relationship was also observed between democracy and real income for some countries. (Glaeser, Ponzetto, \& Shleifer, 2006) studied the relationship between democracy and education. The researchers established a model indicating the importance of schooling in improving civic participation which can facilitate elements of democracy such as voting and political organization.

(Stasavage, 2005) also investigated the relationship between democracy and education spending in Africa. The results suggested that African governments elected through the democratic process spent more on primary education, establishing a positive relationship between democracy and education.

\subsection{Research Questions}

We will be attempting to answer the following questions: 


\section{Macrothink}

- What is the impact of political polarization on the social capital, democracy, and economic growth of countries?

- How does this impact vary across developed, developing, and least developed countries?

- What factors contribute to the positive or negative relationship between polarization and social capital, democracy, and economic growth of countries?

\subsection{Theoretical Framework}

\subsubsection{Understanding Polarization, Democracy, and Social Capital}

Democracy can be defined as a system of governance that is established for managing competing interests within a country or society in a peaceful manner. All parties must follow a set of laws that have previously been agreed upon (Przeworski, 1986).

Polarization measures the difference in opinions and expectations from the different democratic institutions and procedures that exist within a democratic state (Stavrakakis, 2018). Extreme polarization occurs when this difference in opinions and expectations lead to the formation of groups (usually two groups are formed). These groups tend to have mutually exclusive characteristics and opinions (Lozada, 2014).

Social capital can be defined as the benefits and opportunities that people can enjoy by being part of a certain community (Bordieu, 1986). It is a resource that exists due to social ties between members of a community (Coleman, 1990).

We measured social capital through four indicators. These have been briefly described below:

- Government effectiveness: Captures perceptions pertaining to the quality of public service and civil service, the independence of these services from political pressure, the quality of policy formulation and implementation, and the credibility of a government.

- Rule of Law: Evaluates perceptions of the various agents of society and the extent to which these agents believe in the laws of the community and abide by them. It also measures the quality of contract enforcement, law enforcement, property rights, and the likelihood of crime and violence occurring in the community.

- Control of corruption: Captures the perceptions regarding the use of public power for private gain and accounts for corruption. It also evaluates the extent to which elite groups may have captured the state to control their interests.

- Regulatory Quality: Used to evaluate a government's ability to formulate and implement effective policies and regulations that promote the development of the private sector within a country.

\subsubsection{How Can Polarization Affect Democracy?}

Some of the most common problems associated with polarization include lack of civility, a legislative gridlock, and a decline of democracy. It promotes a camp mentality where supporters of a political ideology reject information that goes against their political beliefs. A 
rise in the levels of polarization can also increase media partiality. This can lead to the dissemination of incorrect information to the public in support of a political agenda that hurts democracy. On the upside, polarization can also lead to greater political mobilization and political participation to improve democracy.

\subsubsection{How Can Polarization Affect Social Capital?}

(Lake \& Huckfeldt, 1998) established a connection between social capital and political participation. As per their research, politically relevant social capital may be generated within a network to promote the political engagement of individuals through voting and activism. Polarization also affects government effectiveness by impacting legislative processes. As per (Jones, 2001) party polarization can cause legislative gridlock. (körösényi, 2013) also suggests that political polarization can inhibit the efficiency of two political groups in reaching consensus on legislative processes. This can contribute to government inefficiency, weakening democracy and social capital.

(Lee, 2015) examined the relationship between political polarization and government effectiveness in the USA. It was observed that although polarization gives rise to more cohesion within political groups, this has had little impact on their effectiveness in enacting policies and matters of governance.

\subsubsection{What Is the Impact of Polarization on Education?}

The impact of polarization on education is unclear. Polarized societies fall victim to confirmation bias and misinformation. It also leads to a decline in objectivity among citizens of a country. Higher levels of education can offset these effects and allow individuals to make informed decisions.

Higher education levels also contribute to social capital and democracy. According to (Ashley et al., 2017), individuals with higher media literacy have a deeper understanding of the political process. They can recognize the challenges faced in politics and engage with people productively to find realistic solutions that benefit all groups.

\subsubsection{What Is the Impact of Polarization on Economic Performance?}

Currently, there is no economic model for describing the effects of political polarization on economic growth. However, several theories discuss the impact of polarization on the economic performance of a country.

It has been observed that polarized countries tend to experience economic growth as per the electoral calendar. This effect is most prominent when elections happen. During such periods, the likelihood of policy changes increases which causes a decline in economic growth.

An indirect, negative relationship has also been established between polarization and economic growth. Polarization increases political instability, leading to higher levels of corruption, and influencing investment decisions which harm economic growth.

Previous studies have also suggested a positive relationship between political polarization and GDP due to higher rates of migration accelerating economic growth. 


\section{Macrothink}

1.8.6 How Can the Effects of Polarization Differ Across Developed, Developing, and least Developed Economies?

The effects of polarization will differ greatly across developed, developing, and least developed countries. We propose that the presence of a robust political infrastructure can dilute the effects of political polarization. Thus, it can be assumed that developed countries are less likely to feel the effects of political polarization on democracy, social capital, and economic growth.

Developing countries and the least developed countries may not benefit from political polarization and it can harm democracy and economic performance of these countries.

The effect of polarization on social capital in these countries is less conclusive. We can assume that higher levels of polarization have an adverse impact on social capital as it increases corruption, erodes trust, and hampers government efficiency.

\section{Method}

This study covers the period from 2009 to 2018 and evaluates the effects of polarization on developed, developing, and least developed economies. We began with identifying and selecting countries based on the state of their economy. This data was taken from the official United Nations website (Country classification - un.org, 2014). While the initial list comprised of approximately 90 countries, our final analysis was based on 59 countries. This included 29 developed countries, 10 developing countries, and 20 least developed countries. Due to the unavailability of data for the variables under study, we could not include the rest of the countries initially selected.

We began by collecting data for measuring the economic growth in each country. The variable GDP per capita (as per current US\$) served as the primary indicator here. This information was obtained from the World Bank database.

To measure democracy, we used Polity 2 as the primary indicator. Polity 2 is an autocracy-democracy index. It ranges between -10 and 10, where -10 indicates a state of total autocracy and 10 indicates a state of total democracy. Polity 2 is a revised and combined polity score. A polity is defined as a distinguished political entity. It refers to a group of people with a singular identity and with the capability to mobilize resources.

As per (Polity2 (Polity IV) - SCO, n.d.), Polity2 is a modified version of the Polity variable that can be used in time-series analyses. It changes the combined annual polity score and makes it simpler to interpret by converting standardized authority scores into conventional scores.

These scores can also be divided into three types of regime categories. These are:

a. Autocracies: A system of government where one person or party has absolute power over a region or a country.

Range: -10 to -6 . 
b. Anocracies: Combine the qualities of democracy and a dictatorship; considered as a partly democratic and partly autocratic system of governance.

Range: -5 to +5 .

c. Democracies: A system of government chosen by the whole population of region or country. It is managed by elected representatives chosen by citizens of the state

Range: +6 to +10 .

The Polity 2 data was obtained from the Polity IV Project, Political Regime Characteristics and Transitions, 1800 - 2018 dataset. The data set measured democratic and autocratic patterns of authority from 1800 to 2018 .

As mentioned earlier we chose 4 indicators for this to measure social capital and provide a comprehensive overview of the level of social capital within a country. These were regulatory quality, rule of law, government effectiveness, and control of corruption. This data was obtained from the Worldwide Governance Indicators published by the World Bank (WGI 2019 Interactive, n.d.). To measure social capital as a single variable, we combined the 4 indicators mentioned above to form one factor. This factor was then employed for data analysis in further steps.

To measure polarization, we obtained data from the Institutional Profiles Database. This data is available on the Worldwide Governance Indicators website (WGI 2019 Interactive > Documentation, n.d.). The primary indicators used to measure polarization were based on the measurement of political stability and absence of violence. We measured this through the following variables.

a. Intensity of internal conflicts (based on ethnicity, religion, or region): Refers to violent situations involving confrontations between government representatives and one or more organized groups. These conflicts may also occur between the groups themselves due to differences in ethnicity, religion, or geographical regions.

b. Intensity of violent activities: Refers to violent activities conducted by underground political organizations within a state or a country.

c. Intensity of social conflicts (does not include land-related conflicts): Refers to social conflicts arising due to reasons such as a difference in language, ethnicity, social status, etc. Social conflicts may not necessarily lead to violence.

It should be noted that we are treating this variable as an inverse measure for polarization. Therefore, any positive relationships observed between political stability and other variables will indicate a negative relationship between polarization and these variables.

We also obtained data for measuring education levels in each country. This variable was included as a control. The data for this was obtained from the education index published by the United Nations Development Program (Human Development Reports, n.d.).

For data analysis, we began by conducting unit root tests on the variables involved for each 


\section{Al Macrothink}

Issues in Economics and Business

ISSN 2377-2301 2020, Vol. 6, No. 1

country set. We also carried out normality tests; however, given the large datasets and varying features of individual countries involved, it is difficult to achieve normality. Formal normality tests tend to reject large sample sizes where even small deviations tend to impact skewness.

We then employed the GMM technique for evaluating the relationships between the variables under study. A bilateral analysis was conducted where we developed 5 models for each dataset. Each model measured the dependency of an individual variable upon other variables.

Table 1. Models used

\begin{tabular}{lll}
\hline Model & Dependent Variable & Independent Variables \\
\hline Model 1 & GDP per capita & Social capital, democracy, education, and political stability \\
Model 2 & Political Stability & Social capital, democracy, education, and GDP per capita \\
Model 3 & Social capital & Democracy, education, GDP per capita, and political stability \\
Model 4 & Democracy & Education, social capital, GDP per capita, and political stability \\
Model 5 & Education & Democracy, social capital, GDP per capita, and political stability \\
\hline
\end{tabular}

We also established correlation levels between variables. Our final results were based on 4 datasets involving 5 models: These were:

Dataset I - Developed countries

Dataset II - Developing countries

Dataset III - Least developed countries

Dataset IV - All countries under consideration

\subsection{Trend Analysis}

Table 2. Political stability, democracy, and social capital values for trend analysis

\begin{tabular}{|c|c|c|c|c|c|c|c|c|c|c|c|}
\hline \multicolumn{4}{|c|}{ Least Developed Countries } & \multicolumn{4}{|c|}{ Developed Countries } & \multicolumn{4}{|c|}{ Developing Countries } \\
\hline & $\begin{array}{l}\text { Political } \\
\text { Stability }\end{array}$ & Democracy & $\begin{array}{l}\text { Social } \\
\text { Capital }\end{array}$ & & $\begin{array}{l}\text { Political } \\
\text { Stability }\end{array}$ & Democracy & $\begin{array}{l}\text { Social } \\
\text { Capital }\end{array}$ & & $\begin{array}{l}\text { Political } \\
\text { Stability }\end{array}$ & Democracy & $\begin{array}{l}\text { Social } \\
\text { Capital }\end{array}$ \\
\hline Madagascar & 0.81 & 7 & 1.546356 & Switzerland & 1 & 10 & 1.4383032 & Kenya & 0.86 & 9 & 1.4451438 \\
\hline BurkinaFaso & 0.8 & 7 & 1.0610307 & Netherlands & 0.97 & 10 & 1.3575289 & Indonesia & 0.83 & 9 & 1.4139309 \\
\hline Mozambique & 0.75 & 7 & 1.0064358 & Lithuania & 0.97 & 10 & 1.222 & India & 0.77 & 9 & 1 \\
\hline Senegal & 0.74 & 6 & 0.9475075 & Australia & 0.97 & 10 & 1.1669763 & South Korea & 0.62 & 8 & 0.4360189 \\
\hline Cambodia & 0.73 & 5 & 0.7884667 & Canada & 0.97 & 10 & 1 & Pakistan & 0.57 & 7 & 0.0856952 \\
\hline
\end{tabular}




\begin{tabular}{|c|c|c|c|c|c|c|c|c|c|c|c|}
\hline Haiti & 0.7 & 5 & 0.6177453 & Austria & 0.96 & 10 & 1 & Malaysia & 0.49 & 6 & -0.3682373 \\
\hline Benin & 0.69 & 5 & 0.5136684 & Denmark & 0.95 & 10 & 0.8608749 & Turkey & 0.4 & 4 & -1 \\
\hline Tanzania & 0.68 & 4 & 0.401553 & Finland & 0.95 & 10 & 0.8547741 & Egypt & 0.33 & -4 & -1 \\
\hline Zambia & 0.64 & 2 & 0.3108789 & Poland & 0.95 & 10 & 0.8339463 & Oman & 0.31 & -8 & -1.0536201 \\
\hline Mauritania & 0.61 & 2 & 0.2519111 & Portugal & 0.94 & 10 & 0.7069328 & UAE & 0.24 & -8 & -1.3259888 \\
\hline Angola & 0.61 & 2 & 0.0068543 & US & 0.94 & 10 & 1 & - & - & - & - \\
\hline Uganda & 0.53 & 1 & -0.0596848 & Japan & 0.92 & 10 & 0 & - & - & - & - \\
\hline Bangladesh & 0.48 & 1 & -0.0891488 & UK & 0.91 & 10 & 0.4379186 & - & - & - & - \\
\hline Yemen & 0.48 & 1 & -0.0992051 & Bulgaria & 0.89 & 10 & 0.4250251 & - & - & - & - \\
\hline Ethiopia & 0.43 & 0 & -0.3340665 & Italy & 0.88 & 10 & 0.3697803 & - & - & - & - \\
\hline Niger & 0.39 & -1 & -0.9509819 & Latvia & 0.88 & 10 & 0 & - & - & - & - \\
\hline Nepal & 0.39 & -2 & -1.3709496 & Romania & 0.86 & 10 & 0 & - & - & - & - \\
\hline Mali & 0.3 & -2 & -1.4236856 & Czech Republic & 0.86 & 10 & -0.20235 & - & - & - & - \\
\hline Chad & 0.25 & -2 & -1.4687635 & Estonia & 0.82 & 10 & -0.2958118 & - & - & - & - \\
\hline Central African Republic & 0.23 & -3 & -1.8251987 & Spain & 0.8 & 10 & 0 & - & - & - & - \\
\hline- & - & - & - & Croatia & 0.79 & 9 & 0 & - & - & - & - \\
\hline- & - & - & - & France & 0.78 & 9 & -1 & - & - & - & - \\
\hline- & - & - & - & Ireland & 0.78 & 9 & -1 & - & - & - & - \\
\hline- & - & - & - & Slovenia & 0.76 & 9 & -1 & - & - & - & - \\
\hline- & - & - & - & Hungary & 0.74 & 9 & -1 & - & - & - & - \\
\hline- & - & - & - & Belgium & 0.74 & 9 & -1.3264342 & - & - & - & - \\
\hline - & - & - & - & Germany & 0.72 & 9 & -1 & - & - & - & - \\
\hline- & - & - & - & Greece & 0.7 & 9 & -1.4551843 & - & - & - & - \\
\hline- & - & - & - & Cyprus & 0.61 & 8 & -2 & - & - & - & - \\
\hline
\end{tabular}

\subsubsection{Polarization}

We have conducted a trend analysis by analyzing average values for polarization for each country-set. Among the Least Developed Countries, Madagascar and Burkina Faso are the most politically stable with low polarization levels. Conversely, Chad and the Central African Republic were the least politically stable and having a highly polarized economy.

For developed countries, Switzerland was the most politically stable while Cyprus was the least politically stable.

Among developing countries, the United Arab Emirates showed the greatest political stability and low polarization levels. South Korea displayed similar trends. The least politically stable country observed was Pakistan, followed closely by Kenya and Turkey.

\subsubsection{Democracy}

We also examined trends for democracy. For the least developed countries, Benin, Senegal, and Zambia ranked the highest while Ethiopia, Mauritania, Chad, and Angola ranked the 
lowest and have an anocratic system of governance.

For developed countries, a majority of the countries had a Polity2 score of 10 . Even the lowest Polity2 score observed for this group was 8 . Thus, all developed countries under consideration had a consolidated democracy.

Among developing countries, Kenya, Indonesia, and India showed the highest levels of democracy. South Korea and Pakistan came second and third respectively. On the other hand, the UAE and Oman showed the lowest scores and have an autocratic system of governance. Interestingly, the UAE also showed the highest level of political stability earlier.

\subsubsection{Social Capital}

When trends for social capital were examined, it was noted that among the Least Developed Countries, Senegal and Burkina Faso showed the highest levels of social capital. These countries also ranked high in terms of democratic governance and political stability, indicating a correlation. Chad and the Central African Republic ranked lowest in terms of Social Capital.

Among Developed Countries, Finland ranked the highest in terms of Social Capital. However, Lithuania, Latvia, Poland, Hungary, Italy, Croatia, Greece, Romania, and Bulgaria showed low levels of social capital.

For developing countries, South Korea and UAE showcased the highest levels of social capital. The lowest levels of social capital were observed for Pakistan and Egypt. This suggests that there is a positive correlation between social capital and political stability.

\section{Data Analysis}

We conducted unit root tests before using the GMM technique to examine the relationship between the variables included in our study. The results were as follows:

Table 3. Summary of unit root tests for developed countries (p-values)

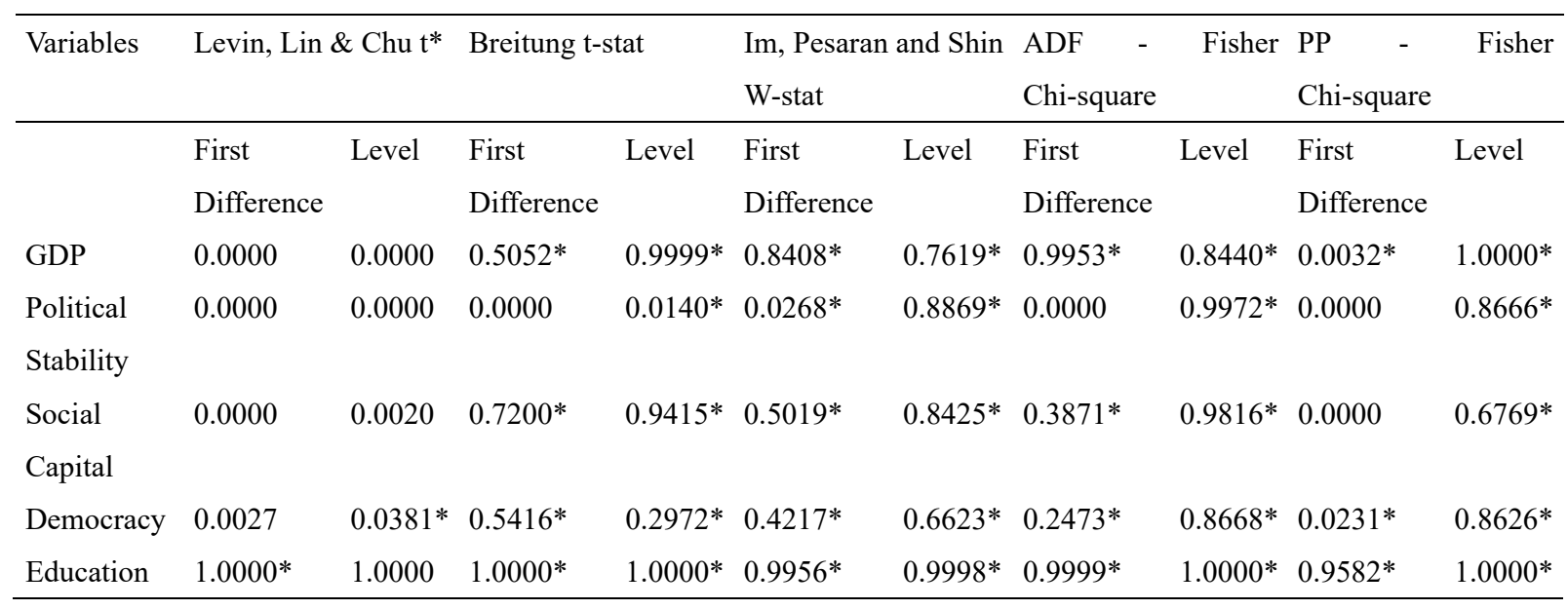




\section{Macrothink}

Table 4. Summary of unit root tests for developing countries ( $p$-values)

\begin{tabular}{|c|c|c|c|c|c|c|c|c|c|c|}
\hline \multirow[t]{2}{*}{ Variables } & \multicolumn{2}{|c|}{ Levin, Lin \& Chu t* } & \multicolumn{2}{|c|}{ Breitung t-stat } & \multicolumn{2}{|c|}{$\begin{array}{c}\text { Im, Pesaran and Shin } \\
\text { W-stat }\end{array}$} & \multicolumn{2}{|c|}{$\begin{array}{l}\text { ADF - Fisher } \\
\text { Chi-square }\end{array}$} & \multicolumn{2}{|c|}{$\begin{array}{l}\text { PP - Fisher } \\
\text { Chi-square }\end{array}$} \\
\hline & $\begin{array}{c}\text { First } \\
\text { Difference }\end{array}$ & Level & $\begin{array}{c}\text { First } \\
\text { Difference }\end{array}$ & Level & $\begin{array}{c}\text { First } \\
\text { Difference }\end{array}$ & Level & $\begin{array}{c}\text { First } \\
\text { Difference }\end{array}$ & Level & $\begin{array}{c}\text { First } \\
\text { Difference }\end{array}$ & Level \\
\hline GDP & 0.0000 & 0.0000 & $0.5638^{*}$ & $0.5004^{*}$ & $0.6075^{*}$ & $0.4635^{*}$ & $0.5019^{*}$ & $0.2282 *$ & 0.0007 & $0.0231 *$ \\
\hline $\begin{array}{l}\text { Political } \\
\text { Stability }\end{array}$ & 0.0000 & 0.0003 & 0.0012 & & & $0.8078^{*}$ & 0.0007 & $0.9847^{*}$ & 0.0000 & $.9098 *$ \\
\hline $\begin{array}{l}\text { Social } \\
\text { Capital }\end{array}$ & $0.1892 *$ & 0.0001 & $0.0163 *$ & $0.9677^{*}$ & $0.6474^{*}$ & $0.5608^{*}$ & $0.7387^{*}$ & $0.4809^{*}$ & 0.0000 & $0.0549 *$ \\
\hline Democracy & 0.0000 & $0.2307^{*}$ & $0.7632 *$ & $0.7140^{*}$ & $0.1314^{*}$ & $0.7795^{*}$ & 0.0062 & $0.9114^{*}$ & 0.0008 & $0.7904 *$ \\
\hline Education & $1.0000 *$ & $1.0000 *$ & $1.0000^{*}$ & $1.0000^{*}$ & $0.9968^{*}$ & $1.0000^{*}$ & $1.0000^{*}$ & $1.0000 *$ & $1.0000^{*}$ & $1.0000 *$ \\
\hline
\end{tabular}

Table 5. Summary of unit root tests for least developed countries (p-values)

\begin{tabular}{|c|c|c|c|c|c|c|c|c|c|c|}
\hline \multirow[t]{3}{*}{ Variables } & \multicolumn{2}{|c|}{ Levin, Lin \& Chu t* } & \multicolumn{2}{|c|}{ Breitung t-stat } & \multirow{2}{*}{\multicolumn{2}{|c|}{$\begin{array}{l}\text { Im, Pesaran and Shin } \\
\text { W-stat }\end{array}$}} & \multirow{2}{*}{$\begin{array}{l}\text { ADF - } \\
\text { Chi-square }\end{array}$} & \multirow[t]{2}{*}{ Fisher } & \multirow{2}{*}{$\begin{array}{l}\mathrm{PP} \quad- \\
\text { Chi-square }\end{array}$} & \multirow[t]{2}{*}{ Fisher } \\
\hline & & & & & & & & & & \\
\hline & First & Level & First & Level & First & Level & First & Level & First & Level \\
\hline & Difference & & Difference & & Difference & & Difference & & Difference & \\
\hline GDP & 0.0000 & 0.0000 & $0.7453^{*}$ & 0.8266 & $0.8072 *$ & $0.6434 *$ & $0.9750^{*}$ & $0.6700^{*}$ & $0.8621^{*}$ & $0.9015^{*}$ \\
\hline Political & 0.0000 & 0.0000 & 0.0014 & 0.0242 & $0.0740 *$ & $0.8353 *$ & 0.0006 & 0.9874* & 0.0000 & $0.7257^{*}$ \\
\hline Stability & & & & & & & & & & \\
\hline Social & 0.0000 & 0.0000 & $0.1001^{*}$ & 0.1442 & $0.4263 *$ & $0.6817 *$ & $0.2070^{*}$ & $0.7902 *$ & 0.0000 & $0.0169^{*}$ \\
\hline Capital & & & & & & & & & & \\
\hline Democracy & 0.0000 & 0.0006 & $0.8608^{*}$ & $0.5131^{*}$ & $0.3247^{*}$ & $0.5823^{*}$ & $0.1022 *$ & $0.6685^{*}$ & 0.0000 & 0.0031 \\
\hline Education & $1.0000^{*}$ & $1.0000 *$ & $1.0000 *$ & $0.1941^{*}$ & $0.9938^{*}$ & $1.0000 *$ & $1.0000 *$ & 1.0000 & 1.0000 & $1.0000^{*}$ \\
\hline
\end{tabular}

Table 6. Summary of unit root tests for all countries (p-values)

\begin{tabular}{|c|c|c|c|c|c|c|c|c|c|c|}
\hline \multirow[t]{3}{*}{ Variables } & \multicolumn{2}{|c|}{ Levin, Lin \& Chu t* } & \multicolumn{2}{|c|}{ Breitung t-stat } & \multirow{2}{*}{\multicolumn{2}{|c|}{$\begin{array}{l}\text { Im, Pesaran and Shin } \\
\text { W-stat }\end{array}$}} & \multirow{2}{*}{$\begin{array}{l}\text { ADF - } \\
\text { Chi-square }\end{array}$} & \multirow[t]{2}{*}{ Fisher } & \multirow{2}{*}{\multicolumn{2}{|c|}{ Chi-square }} \\
\hline & & & & & & & & & & \\
\hline & First & Level & First & Level & First & Level & First & Level & First & Level \\
\hline & Difference & & Difference & & Difference & & Difference & & Difference & \\
\hline GDP & 0.0000 & 0.0000 & $0.6814^{*}$ & $0.9972 *$ & $0.9061^{*}$ & $0.7504 *$ & $0.9985^{*}$ & $0.7549 *$ & 0.0015 & $0.9833^{*}$ \\
\hline Political & 0.0000 & 0.0000 & 0.0000 & 0.0006 & 0.0024 & $0.9621 *$ & 0.0000 & $1.0000^{*}$ & 0.0000 & $0.9595 *$ \\
\hline Stabili & & & & & & & & & & \\
\hline Social & 0.0000 & 0.0000 & $0.1284^{*}$ & $0.9164 *$ & $0.4332 *$ & $0.8390 *$ & $0.2005^{*}$ & $0.9561^{*}$ & 0.0000 & 0.0013 \\
\hline Capital & & & & & & & & & & \\
\hline Democracy & 0.0000 & 0.0002 & $0.9056^{*}$ & $0.5455^{*}$ & $0.1466^{*}$ & $0.7701 *$ & 0.0052 & $0.9347^{*}$ & 0.0000 & $0.0520 *$ \\
\hline Education & $1.0000^{*}$ & $1.0000 *$ & $1.0000 *$ & $0.9982 *$ & $1.0000 *$ & $1.0000^{*}$ & $1.0000 *$ & $1.0000 *$ & $1.0000^{*}$ & $1.0000 *$ \\
\hline
\end{tabular}

*represents stationary values at greater than $1 \%$ and $5 \%$ respectively. 


\section{Macrothink}

Table 7. Results for Model I - II for Developed countries

\begin{tabular}{llllll}
\hline \multicolumn{2}{l}{ Model I - Dependent Variable: GDP per Capita } & \multicolumn{4}{l}{ Model II - Dependent Variable: Education } \\
\hline Independent Variables & Probability & Relationship & Independent Variables & Probability & Relationship \\
Political Stability & 0.0000 & Insignificant & Political Stability & 0.0000 & Insignificant \\
Social Capital & 0.0000 & Insignificant & Social Capital & 0.0000 & Insignificant \\
Democracy & 0.3699 & Insignificant & Democracy & 0.0001 & Positive and significant \\
Education & 0.0000 & Insignificant & GDP & 0.0000 & Insignificant \\
\hline
\end{tabular}

Table 8. Results for Model III - IV for Developed countries

\begin{tabular}{|c|c|c|c|c|c|c|c|}
\hline \multicolumn{4}{|c|}{ Model III - Dependent Variable: Social Capital } & \multicolumn{4}{|c|}{ Model IV - Dependent Variable: Democracy } \\
\hline Independent & Probability & Relationship & & Independent & Probability & Relationship & \\
\hline Variables & & & & Variables & & & \\
\hline Political Stability & 0.0271 & $\begin{array}{l}\text { Positive } \\
\text { significant }\end{array}$ & and & Political Stability & 0.1958 & Insignificant & \\
\hline Education & 0.2377 & Insignificant & & Social Capital & 0.0310 & $\begin{array}{l}\text { Positive } \\
\text { significant }\end{array}$ & and \\
\hline Democracy & 0.0362 & $\begin{array}{l}\text { Positive } \\
\text { significant }\end{array}$ & and & Education & 0.7683 & Insignificant & \\
\hline GDP & 0.0000 & Insignificant & & GDP & 0.9051 & Insignificant & \\
\hline
\end{tabular}

Table 9. Results for Model V for Developed countries

\begin{tabular}{lcl}
\hline \multicolumn{2}{l}{ Model V - Dependent Variable: Political Stability } & \\
\hline Independent Variables & Probability & Relationship \\
Democracy & 0.2120 & Insignificant \\
Social Capital & 0.0002 & Positive and significant \\
Education & 0.0000 & Insignificant \\
GDP & 0.0001 & Positive and significant \\
\hline
\end{tabular}

Table 10. Correlation results for developed countries

\begin{tabular}{lccccc}
\hline Correlation & Social Capital & GDP per capita & Education & Democracy & Polarization \\
\hline Social Capital & 1.000000 & 0.835190 & 0.852188 & 0.206958 & 0.305621 \\
GDP per capita & 0.835190 & 1.000000 & 0.846922 & 0.186087 & 0.254226 \\
Education & 0.852188 & 0.846922 & 1.000000 & 0.170850 & 0.131632 \\
Democracy & 0.206958 & 0.186087 & 0.170850 & 1.000000 & 0.188424 \\
Polarization & 0.305621 & 0.254226 & 0.131632 & 0.188424 & 1.000000 \\
\hline
\end{tabular}




\section{Macrothink}

Issues in Economics and Business

ISSN 2377-2301 2020, Vol. 6, No. 1

Table 11. Results for Model I - II for Least developed countries

\begin{tabular}{|c|c|c|c|c|c|}
\hline \multicolumn{3}{|c|}{ Model I - Dependent Variable: GDP } & \multicolumn{3}{|c|}{ Model II - Dependent Variable: Education } \\
\hline Independent & Probability & Relationship & Independent Variables & Probability & Relationship \\
\hline \multicolumn{6}{|l|}{ Variables } \\
\hline Political Stability & 0.0000 & Insignificant & Political Stability & 0.4375 & Insignificant \\
\hline Social Capital & 0.0000 & Insignificant & Social Capital & 0.0532 & $\begin{array}{l}\text { Positive and } \\
\text { significant }\end{array}$ \\
\hline Democracy & 0.5471 & Insignificant & Democracy & 0.0739 & $\begin{array}{l}\text { Positive and } \\
\text { significant }\end{array}$ \\
\hline Education & 0.9955 & Insignificant & GDP & 0.0119 & $\begin{array}{l}\text { Positive and } \\
\text { significant }\end{array}$ \\
\hline
\end{tabular}

Table 12. Results for Model III - IV for Least developed countries

\begin{tabular}{llllll}
\hline \multicolumn{2}{l}{ Model III - Dependent Variable: Social Capital } & \multicolumn{4}{l}{ Model IV - Dependent Variable: Democracy } \\
\hline Independent Variables & Probability & Relationship & Independent Variables & Probability & Relationship \\
Political Stability & 0.4662 & Insignificant & Political Stability & 0.5102 & Insignificant \\
Education & 0.4190 & Insignificant & Social Capital & 0.0000 & Insignificant \\
Democracy & 0.5098 & Insignificant & Education & 0.0000 & Insignificant \\
GDP & 0.6311 & Insignificant & GDP & 0.0000 & Insignificant \\
\hline
\end{tabular}

Table 13. Results for Model V for Least developed countries

\begin{tabular}{lcl}
\hline \multicolumn{2}{l}{ Model V - Dependent Variable: Political Stability } & \\
\hline Independent Variables & Probability & Relationship \\
Democracy & 0.0792 & Positive and significant \\
Social Capital & 0.0000 & Insignificant \\
Education & 0.0836 & Positive and significant \\
GDP & 0.0599 & Positive and significant \\
\hline
\end{tabular}

Table 14. Correlation Results for Least developed countries

\begin{tabular}{lccccc}
\hline Correlation & GDP per capita & Education & Democracy & Political Stability & Social Capital \\
\hline GDP per capita & 1.000000 & 0.421422 & -0.230806 & 0.067180 & -0.14324 \\
Education & 0.421422 & 1.000000 & 0.036716 & 0.282035 & 0.136648 \\
Democracy & -0.23081 & 0.036716 & 1.000000 & 0.149445 & 0.366106 \\
Political Stability & 0.067180 & 0.282035 & 0.149445 & 1.000000 & 0.354522 \\
Social Capital & -0.14324 & 0.136648 & 0.366106 & 0.354522 & 1.000000 \\
\hline
\end{tabular}




\section{Macrothink}

Issues in Economics and Business

ISSN 2377-2301 2020, Vol. 6, No. 1

Table 15. Results for Model I - II for Developing countries

\begin{tabular}{llllll}
\hline Model I - Dependent Variable: GDP & & \multicolumn{4}{l}{ Model II - Dependent Variable: Education } \\
\hline Independent Variables & Probability & Relationship & Independent Variables & Probability & Relationship \\
Political Stability & 0.0112 & Positive and significant & Political Stability & 0.1853 & Insignificant \\
Social Capital & 0.1122 & Insignificant & Social Capital & 0.6584 & Insignificant \\
Democracy & 0.0000 & Insignificant & Democracy & 0.4090 & Insignificant \\
Education & 0.9765 & Insignificant & GDP & 0.4705 & Insignificant \\
\hline
\end{tabular}

Table 16. Results for Model 1II - IV for Developing countries

\begin{tabular}{llllll}
\hline \multicolumn{2}{l}{ Model III - Dependent Variable: Social Capital } & \multicolumn{4}{l}{ Model IV - Dependent Variable: Democracy } \\
\hline Independent Variables & Probability & Relationship & Independent Variables & Probability & Relationship \\
Political Stability & 0.1098 & Insignificant & Political Stability & 0.4335 & Insignificant \\
Education & 0.9251 & Insignificant & Social Capital & 0.2574 & Insignificant \\
Democracy & 0.0510 & Positive and significant & Education & 0.2201 & Insignificant \\
GDP & 0.0571 & Positive and significant & GDP & 0.6031 & Insignificant \\
\hline
\end{tabular}

Table 17. Results for Model V for Developing countries

\begin{tabular}{lcl}
\hline \multicolumn{2}{l}{ Model V - Dependent Variable: Political Stability } & \\
\hline Independent Variables & Probability & Relationship \\
Democracy & 0.9891 & Insignificant \\
Social Capital & 0.2533 & Insignificant \\
Education & 0.4241 & Insignificant \\
GDP & 0.0002 & Positive and significant \\
\hline
\end{tabular}

Table 18. Correlation results for developing countries

\begin{tabular}{lccccc}
\hline Correlation & GDP per capita & Democracy & Education & Political Stability & Social Capital \\
\hline GDP per capita & 1.000000 & -0.543181 & 0.805946 & 0.710885 & 0.854613 \\
Democracy & -0.54318 & 1.000000 & -0.41951 & -0.409445 & -0.26472 \\
Education & 0.805946 & -0.419513 & 1.000000 & 0.715835 & 0.880814 \\
Political Stability & 0.710885 & -0.409445 & 0.715835 & 1.000000 & 0.723120 \\
Social Capital & 0.854613 & -0.264719 & 0.880814 & 0.723120 & 1.000000 \\
\hline
\end{tabular}




\section{Macrothink}

Table 19. Results for Model I - II for all countries

\begin{tabular}{|c|c|c|c|c|c|c|c|}
\hline \multicolumn{4}{|c|}{ Model I - Dependent Variable: GDP } & \multicolumn{4}{|c|}{ Model II - Dependent Variable: Education } \\
\hline Independent & Probability & Relationship & & Independent & Probability & Relationship & \\
\hline Variables & & & & Variables & & & \\
\hline Political Stability & 0.0261 & $\begin{array}{l}\text { Positive } \\
\text { significant }\end{array}$ & and & Political Stability & 0.0000 & Insignificant & \\
\hline Social Capital & 0.0000 & Insignificant & & Social Capital & 0.0005 & $\begin{array}{l}\text { Positive } \\
\text { significant }\end{array}$ & and \\
\hline Democracy & 0.0000 & Insignificant & & Democracy & 0.0047 & $\begin{array}{l}\text { Positive } \\
\text { significant }\end{array}$ & and \\
\hline Education & 0.0000 & Insignificant & & GDP & 0.0000 & Insignificant & \\
\hline
\end{tabular}

Table 20. Results for Model III - IV for all countries

\begin{tabular}{|c|c|c|c|c|c|c|c|}
\hline \multicolumn{4}{|c|}{ Model III - Dependent Variable: Social Capital } & \multicolumn{4}{|c|}{ Model IV - Dependent Variable: Democracy } \\
\hline Independent & Probability & Relationship & & Independent & Probability & Relationship & \\
\hline Variables & & & & Variables & & & \\
\hline Political Stability & 0.6873 & Insignificant & & Political Stability & 0.0000 & Insignificant & \\
\hline Education & 0.1263 & Insignificant & & Social Capital & 0.0000 & Insignificant & \\
\hline Democracy & 0.0000 & Insignificant & & Education & 0.0865 & $\begin{array}{l}\text { Positive } \\
\text { significant }\end{array}$ & and \\
\hline GDP & 0.0244 & $\begin{array}{l}\text { Positive } \\
\text { significant }\end{array}$ & and & GDP & 0.1116 & Insignificant & \\
\hline
\end{tabular}

Table 21. Results for Model V for All countries

\begin{tabular}{lll}
\hline \multicolumn{2}{l}{ Model V - Dependent Variable: Political Stability } & \\
\hline Independent Variables & Probability & Relationship \\
Democracy & 0.1939 & Insignificant \\
Social Capital & 0.0000 & Insignificant \\
Education & 0.0056 & Positive and significant \\
GDP & 0.2252 & Insignificant \\
\hline
\end{tabular}

Table 22. Correlation results for All Countries

\begin{tabular}{lccccc}
\hline Correlation & GDP per capita & Education & Democracy & Political Stability & Social Capital \\
\hline GDP per capita & 1.000000 & 0.800380 & 0.455389 & 0.575130 & 0.888637 \\
Education & 0.800380 & 1.000000 & 0.562936 & 0.619427 & 0.905582 \\
Democracy & 0.455389 & 0.562936 & 1.000000 & 0.393541 & 0.600048 \\
Political Stability & 0.575130 & 0.619427 & 0.393541 & 1.000000 & 0.658949 \\
Social Capital & 0.888637 & 0.905582 & 0.600048 & 0.658949 & 1.000000 \\
\hline
\end{tabular}




\section{Results}

\subsection{Effect of Polarization on Democracy, Social Capital, Education, and Growth of Developed Countries}

We began by evaluating the relationship between GDP per capita (dependent variable) and political stability, social capital, education, and democracy. All relationships were found to be insignificant.

When examining the relationship between education (dependent variable) and political stability, social capital, democracy, and GDP per capita, it was observed that except democracy, all other relationships were insignificant. There appears to be a weak, positive, and significant relationship between democracy and education, indicating that an increase in democracy also improves the education index.

Next, we examined the relationship between social capital (dependent variable) and political stability, education, and democracy, and GDP per capita. This variable did not have a significant relationship with education and GDP per capita. However, there was a positive and significant relationship between social capital and political stability. This indicates a negative and significant relationship between polarization and social capital. A positive and significant relationship was also observed for social capital and democracy.

We also examined the relationship between democracy (dependent variable) and political stability, social capital, education, and GDP per capita. There is a positive and significant relationship between democracy and social capital. All other relationships were insignificant.

Finally, we ascertained the relationship between political stability (dependent variable) and democracy, social capital, education, and GDP per capita. The relationships between political stability and democracy, as well as education, were insignificant. However, political stability appeared to have a weak, positive, and significant relationship with social capital and GDP per capita. An increase in these variables would cause a minor decrease in polarization.

4.2 Effect of Polarization on Democracy, Social Capital, and Economic Growth of Least Developed Countrie

No significance was observed for the relationships between GDP per capita (dependent variable) and political stability, social capital, democracy, and education.

We also studied the relationship between education (dependent variable) and political stability, social capital, democracy, and GDP per capita. Except for political stability, all relationships were positive and significant.

Next, we examined the relationship between social capital (dependent variable) and political, education, democracy, and GDP per capita. All relationships were insignificant. No signiciant relationship existed between democracy (dependent variable) and political stability, social capital, education, and GDP per capita, as well.

Our final model evaluated the relationship between political stability (dependent variable) and social capital, democracy, GDP per capita, and education. Except social capital, all 
relationships were found to be positive and significant.

\subsection{Effect of Polarization on Democracy, Social Capital, and Growth of Developing Countries}

We began by determining the relationship between GDP per capita (dependent variable) and political stability, social capital, democracy, and education. There was no significant relationship between GDP per capita and social capital, democracy, and education. However, there appears to be a positive relationship between GDP per capita and political stability. This indicates that a decrease in polarization increases the GDP per capita of developing countries.

For our second model, we observed the relationship between education (dependent variable) and political stability, social capital, GDP per capita, and democracy. No significant relationships were observed.

In the third model, we evaluated the relationship between social capital (dependent variable) and political stability, education, democracy, and GDP per capita. A positive and significant relationship was observed between social capital and democracy and social capital and GDP per capita. Other relationships were insignificant.

Our fourth model examined the relationship between democracy (dependent variable) and political stability, social capital, education, and GDP per capita. No significant relationship was found.

Finally, we observed the relationship between political stability (dependent variable) and social capital, democracy, education, and GDP per capita. There appears to be a weak yet positive and significant relationship between political stability and GDP per capita indicating that an increase in GDP per capita leads to a minor decrease in polarization. No other significant relationships were found.

\subsection{Effect of polarization on Democracy, Social Capital, and Economic Growth of All Countries}

We also evaluated the relationships between these variables for all the countries included in our study. In Model 1, we examined the relationship between GDP per capita (dependent variable) and political stability, social capital, democracy, and education. With the exception of political stability, all other relationships were statistically insignificant. Political stability has a positive impact on GDP per capita, indicating that an increase in polarization levels decreases GDP per capita.

Our second model evaluated the relationship between education (dependent variable) and social capital, political stability, democracy, and GDP per capita. We discovered a positive and significant relationship between education and social capital and democracy. No other significant relationships were found.

In Model 3, we determined the impact of political stability, education, democracy, and GDP per capita on social capital. Except for GDP per capita, all other relationships were statistically insignificant. It appears that an increase in GDP per capita of countries also 
causes an increase in social capital levels.

Our fourth model focused on the relationship between democracy (dependent variable) and political stability, social capital, education, and GDP per capita. The only significant and positive relationship that was observed was between democracy and education.

Our final model evaluated the relationship between political stability (dependent variable) and democracy, social capital, education, and GDP per capita. The only positive and significant relationship here was between political stability and education and it appears that an increase in the education index can decrease in polarization levels

\section{Discussion}

As per our results, polarization appears to be inversely linked to economic growth. This can be because political instability resulting from internal conflicts, political violence, and social conflicts influences activities that stimulate economic growth. Such conflicts can affect business productivity, foreign investment, and industrial output, thereby harming GDP per capita. A similar relationship has been discussed in previous studies. Our study has confirmed these findings.

Further, we investigated the effects of polarization on social capital and democracy. It appears that polarization has a significant and negative impact on social capital in developed countries. We propose this is because polarization can lead to legislative gridlock. The lack of cooperation between various political groups can prevent government bodies from fulfilling their responsibilities towards citizens. This prevents the formation and implementation of policies and inhibits government effectiveness. Polarization can also induce corruption, weaken civic norms, and cause a decline in the rule of law, thereby diminishing social capital.

The effect of polarization on the social capital levels of least developed and developing countries did not prove to be significant. An analysis of all the countries under study produced the same results.

Polarization does not have a significant impact on democracy and education in developed, least developed, and developing countries, as well. Our assumption that change in the levels of political polarization can hurt democracy is therefore rejected.

When determining the effect of these variables on polarization, the following relationships were discovered:

Social capital appears to have a significant and negative relationship with political polarization in developed countries. GDP per capita also has a weak yet negative effect on polarization. In the case of least developed countries, democracy, education, and GDP per capita all have a negative impact on polarization. An increase in democracy automatically decreases polarization due to greater political stability and fewer ethnic and religious conflicts.

An improvement in the education index also reduces polarization. This is because a higher education index prevents misinformation, improves social relations, reduces internal ethnic 
and religious conflicts, and prevents violence.

An increase in GDP per capita also decreases polarization by improving the quality of life and reducing conflicts occurring due to the unequal distribution of wealth and rights. For least developed countries, an improvement in economic growth can help resolve internal and social conflicts and political violence in these countries.

For developing countries, GDP per capita was the only variable to have a significant and negative impact on polarization levels. We can assume that this relationship exists for the same reasons that have been discussed above. In our final analysis (involving all countries), an inverse relationship was observed for education and polarization, indicating that an improvement in the education index causes polarization to decrease, as well. This relationship has been discussed above.

We also found positive and significant relationships between the following:

Increase in social capital, democracy and economic growth has a positive impact on the education index of least developed countries. This confirms the role of these variables in elevating literacy levels of least developed countries.

We also observed positive relationships between social capital and democracy and social capital and GDP per capita for developing countries. This confirms that an increase in democracy also increases government effectiveness, rule of law, regulatory quality, and control of corruption. It plays a foundational role in the development of these economies. The same can be said for the relationship between GDP per capita and social capital. Better economic growth allows governments to function more effectively, improves regulatory quality, and reduces corruption. This can increase trust levels among citizens. GDP per capita is an effective measure of the income level of a citizen, as well. Previous studies have demonstrated that higher and equal income levels increase social capital. The positive relationship established between GDP per capita and social capital confirms these findings.

Finally, we discovered a positive and significant relationship between education and social capital and democracy for all countries. This is aligned with our findings regarding the individual effects of these variables on the education index of developed, developing, and least developed countries.

\section{Conclusion}

Prior to this study, there was no economic model for explaining the impact of political polarization on economic development. Studies focusing on political polarization and its effects on social capital, democracy, and economic growth were limited to a particular country or region. We have addressed this gap by conducting a study focusing on developed, developing, and least developed countries.

We also examined the relationship between social capital and political polarization. Given how there is little literature available on political polarization and social capital, this study is among the first to describe the relationship between social capital and political polarization. Previous studies on social capital revolved around financial development, democracy, and 
economic growth. We have determined that polarization appears to have a negative impact on social capital, as well.

The significance and implication of these results help us understand the role of political polarization in shaping developed, developing, and least developing economies. Developed economies must strive to reduce political polarization by resolving internal conflicts and preventing political violence to spur economic growth. This can also improve government effectiveness, rule of law, regulatory quality, and control of corruption in developed countries. Finally, an increase in democracy appears to reduce political polarization in the least developed countries. Additionally, investing in better schooling and improving the education infrastructure in these countries can lead to political stability.

\section{References}

Acemoglu, D., Naidu, S., Restrepo, P., \& Robinson, J. (2014). Democracy Does Cause Growth. https://doi.org/10.3386/w20004

Ashley, S., Maksl, A., \& Craft, S. (2017). News Media Literacy and Political Engagement: What's the Connection? Journal of Media Literacy Education, 9(1), 79-98. https://doi.org/10.23860/JMLE-2017-9-1-6

Bove, V., \& Elia, L. (2017). Migration, Diversity, and Economic Growth. World Development, 89, 227-239. https://doi.org/10.1016/j.worlddev.2016.08.012

Brzezinski, M. B. (2013). Income Polarization and Economic Growth. SSRN Electronic Journal. https://doi.org/10.2139/ssrn.2244858

Deth, Jan W. van. (2007). The Proof of the Pudding: Social Capital, Democracy, and Citizenship.

Enyedi, Z. (2006). Party Politics in Post-Communist Transition. Handbook of Party Politics, 228-238. https://doi.org/10.4135/9781848608047.n20

Enyedi, Z. (2008). The Social and Attitudinal Basis of Political Parties: Cleavage Politics Revisited European Review, 16(3), 287-304. https://doi.org/10.1017/S1062798708000264

Giorgos, K. Y. S., Katsambekis, G., \& Stavrakakis, Y. (2013, July 23). Populism, anti-populism and European democracy: A view from the South. Retrieved June 19, 2020, from https://www.opendemocracy.net/en/can-europe-make-it/populism-anti-populism-andeuropean-democr/

Glaeser, E., Ponzetto, G., \& Shleifer, A. (2006). Why Does Democracy Need Education? Journal of Economic Growth, 12, 77-99. https://doi.org/10.1007/s10887-007-9015-1

Glassman, M. (2017). Campbell, James E. Polarized: Making Sense of a Divided America. Congress \& the Presidency, 44(2), 285-286. https://doi.org/10.1080/07343469.2017.1314721

Guiso, L. G. (2000). The Role of Social Capital in Financial Development. American Economic Review. https://doi.org/10.3386/w7563 
Gylfason, T. (2019). Inequality Undermines Democracy and Growth. In L. Paganetto (Ed.), Yearning for Inclusive Growth and Development, Good Jobs and Sustainability (pp. 137-158). Springer International Publishing. https://doi.org/10.1007/978-3-030-23053-1_9

Houston, D. (2019). Polarization and the Politics of Education: What Moves Partisan Opinion? Educational Policy, 089590481882374.

Human Development Reports. (n.d.). Retrieved February 1, 2020, from http://hdr.undp.org/en/indicators/103706\#

Jones, D. R. (2001). Party Polarization and Legislative Gridlock. Political Research Quarterly, 54(1), 125. https://doi.org/10.1177/106591290105400107

Karnane, P., \& Quinn, M. A. (2019). Political instability, ethnic fractionalization and economic growth. International Economics and Economic Policy, 16(2), 435-461. https://doi.org/10.1007/s10368-017-0393-3

Knack, S., \& Keefer, P. (1997). Does Social Capital Have an Economic Payoff? A Cross-Country Investigation. The Quarterly Journal of Economics, 112(4), 1251-1288. https://doi.org/10.1162/003355300555475

körösényi, andrás. (2013). Political polarization and its consequences on democratic accountability. Corvinus journal of sociology and social policy. 4.

Lake, R. L. D., \& Huckfeldt, R. (1998). Social Capital, Social Networks, and Political Participation. Political Psychology, 19(3), 567-584. https://doi.org/10.1111/0162-895X.00118

Lebas, A. (2011). Opposition Parties and Democratization in Africa. From Protest to Parties, 3-19. https://doi.org/10.1093/acprof:oso/9780199546862.003.0001

Lebas, A. (2018). Can Polarization Be Positive? Conflict and Institutional Development in Africa. American Behavioral Scientist, 62(1), 59-74. https://doi.org/10.1177/0002764 218756923

Lee, F. E. (2015). How Party Polarization Affects Governance. Annual Review of Political Science, 18(1), 261-282. https://doi.org/10.1146/annurev-polisci-072012-113747

Marsh, C. (2000). Social capital and democracy in Russia. Communist and Post-Communist Studies, 33(2), 183-199. https://doi.org/10.1016/S0967-067X(00)00003-9

McCoy, J., Rahman, T., \& Somer, M. (2018). Polarization and the Global Crisis of Democracy: Common Patterns, Dynamics, and Pernicious Consequences for Democratic Polities. American Behavioral Scientist, 62(1), 16-42. https://doi.org/10.1177/000276 4218759576

Montalvo, J. G., \& Reynal-Querol, M. (2003). Religious polarization and economic development. Economics Letters, 80(2), 201-210. https://doi.org/10.1016/S0165-1765 (03)00080-6

Moreno, A. (2017). Ryan E. Carlin, Matthew M. Singer y Elizabeth J. Zechmeister (eds.). 


\section{Macrothink}

Issues in Economics and Business

ISSN 2377-2301 2020, Vol. 6, No. 1

The Latin American Voter: Pursuing Representation and Accountability in Challenging Contexts, Ann Arbor, University of Michigan Press, 2015, 428 pp. Perfiles Latinoamericanos, 25(49), 325-335. https://doi.org/10.18504/p12549-014-2017

Narayan, P. K., Narayan, S., \& Smyth, R. (2011). Does democracy facilitate economic growth or does economic growth facilitate democracy? An empirical study of Sub-Saharan Africa. Economic Modelling, 28(3), 900-910.

Polity2 (Polity IV)-SCO. (n.d.). Retrieved March 15, 2020, from https://competitivite.ferdi.fr/en/indicators/polity2-polity-iv

Przeworski, A. (1986). Some Problems in the Study of the Transition to Democracy. In G. O'Donnell, P. C. Schmitter, \& L. Whitehead (Eds.), Transitions From Authoritarian Rule: Comparative Perspectives (Vol. 3). Baltimore and London: The Johns Hopkins University Press.

Stasavage, D. (2005). Democracy and Education Spending in Africa. American Journal of Political Science, 49(2), 343-358.

Stavrakakis, Y. (2018). Populism, Anti-Populism and Democracy. Political Insight, 9(3), 33-35. https://doi.org/10.1177/2041905818796577

Tavits, M. (2006). Making Democracy Work More? Exploring the Linkage between Social Capital and Government Performance. Political Research Quarterly, 59(2), 211-225. https://doi.org/10.1177/106591290605900204

\section{Copyright Disclaimer}

Copyright for this article is retained by the author(s), with first publication rights granted to the journal. This is an open-access article distributed under the terms and conditions of the Creative Commons Attribution license (http://creativecommons.org/licenses/by/4.0/). 